\title{
Retinal imaging via the implantable miniature telescope
}

\author{
Kirk A J Stephenson 지, ${ }^{1}$ Geoffroy Meynet, ${ }^{1}$ Eli Aharoni, ${ }^{2}$ David J Keegan ${ }^{1}$
}

'Ophthalmology, Mater Private Hospital, Dublin, Ireland ${ }^{2}$ VisionCare Ophthalmic Technologies (Samsara Vision), Saratoga, California, USA

\section{Correspondence to}

Dr Kirk A J Stephenson; kirkstephenson@hotmail.com

Accepted 6 July 2021
Check for updates

(c) BMJ Publishing Group Limited 2021. No commercial re-use. See rights and permissions. Published by BMJ.

To cite: Stephenson KAJ Meynet $\mathrm{G}$, Aharoni $\mathrm{E}$ et al. BMJ Case Rep

2021;14:e243242.

doi:10.1136/bcr-2021-

243242

\section{DESCRIPTION}

A 78-year-old man presented with moderate lens opacity and end-stage dry age-related macular degeneration (AMD) with visual acuity of $\log$ MAR 0.7 and 1.6 for right and left eyes, respectively. $\mathrm{He}$ was tested with an external telescope simulator device, showing an improvement of 20 letters and 2 letters for right and left eyes, respectively. $\mathrm{He}$ consented for right cataract extraction and insertion of an Implantable Miniature Telescope (IMT, by Dr. Isaac Lipshitz, VisionCare Ophthalmic Technologies, California, USA). The surgery was conducted under regional anaesthesia. Routine small-incision phacoemulsification was followed by IMT implantation into the capsular bag via a $12 \mathrm{~mm}$ corneal limbal incision, peripheral iridectomy formation and corneal closure with interrupted 10/0 nylon sutures (figure 1A).

Best-corrected visual acuity (BCVA) in the IMTimplanted eye was measured at $\operatorname{logMAR} 0.3$ at 6 months and again at 2 years; however, at 3 years, BCVA had deteriorated to $\log$ MAR 0.6 due to progressive enlargement of macular geographic atrophy beyond the area of image magnification. IMT position was stable (figure 1B) and corneal endothelial cell count reduced by $6 \%$ at 2 years, comparable with a standard anterior chamber lens. ${ }^{1}$

AMD is the most common cause of visual loss in adults $>50$ years in the developed world, affecting one-third of the $>75$ years population, typically bilaterally. ${ }^{2}{ }^{3}$ Treatment is available for the neovascular form of AMD; however, therapies for dry AMD are currently limited. ${ }^{4}$ The proportion of AMD patients with significant visual loss (>6 lines of BCVA loss) increases with disease duration and development of end-stage features including geographic atrophy and subretinal scarring. ${ }^{4}$ AMD, particularly bilateral advanced disease, has a negative effect on quality of life

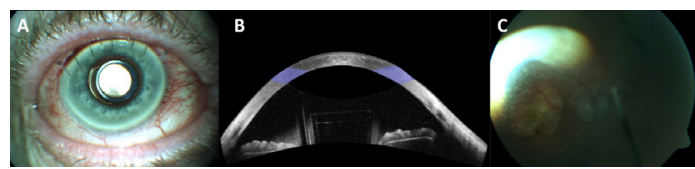

Figure 1 (A) Anterior segment photograph (FF450plus, Carl Zeiss MediTec, Dublin, California, USA) showing IMT device in the capsular bag and superior corneal sutures. (B) Anterior segment OCT (Cirrus 5000, Carl Zeiss MediTec) showing position of the IMT optic placed in the pupil margin with adequate lens-endothelial clearance. (C) Colour fundus photograph (FF450plus, Carl Zeiss MediTec) through the IMT demonstrating visualisation of the optic nerve head and macula. IMT, implantable miniature telescope; OCT, optical coherence tomography.

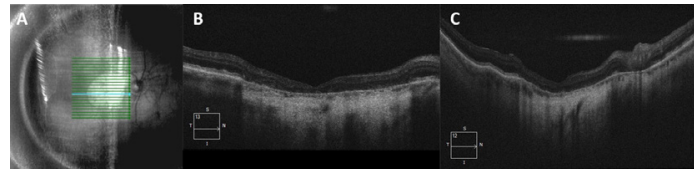

Figure 2 Optical coherence tomography (OCT) (Cirrus 5000, Carl Zeiss Meditec, Dublin, California, USA) images showing $(A)$ en face view of retina extending to the arcades, (B) macular view OCT B-scan, highlighting geographic outer retinal atrophy and (C) wide field OCT B-scan.

(QOL) with better QOL outcomes when low vision aid training is instituted. ${ }^{5}$

Low vision devices (eg, handheld magnifiers) have long been the mainstay of treatment in advanced AMD but may be limited by musculoskeletal comorbidity. ${ }^{6}$ Novel intraocular magnifiers are now available as an adjunct to cataract surgery. ${ }^{7}$ The IMT (by Dr Isaac Lipshitz) is a miniaturised Galilean telescope which magnifies image size on the macula by $\times 2.7$, engaging viable retina surrounding a central scar/atrophy providing BCVA gain of $\geq 2$ lines in $90 \%$ when implanted in the better-seeing eye. ${ }^{7}$ Data from FDA studies and our own work show long-term preservation of corneal endothelial

\section{Learning points}

The implantable miniature telescope (IMT) may provide functional benefit in advanced agerelated macular degeneration (AMD) (though not a return to driving vision) with good safety parameters in appropriate patients (ie, no peripheral retinal pathology, motivated to participate in visual rehabilitation training).

- Careful preoperative assessment of benefit and safety should be performed with both anatomical measurements (ie, anterior chamber depth, axial length, endothelial cell count) and proprietary external telescope simulator, which illustrates magnification, field of vision and contrast to be expected via the IMT.

- Retinal examination and imaging can be readily performed through the IMT device for AMD monitoring and treatment. While colour photographs are hampered by glare/artefact, Zeiss Cirrus 5000 optical coherence tomography images can be successfully acquired via the high-definition raster mode with line spacing $0.1-0.25 \mathrm{~mm}$ (ie, tightly packed), line length 3-6 mm, scan angle $0^{\circ}$, and any eye-tracking features deactivated. 
cell count comparable with traditional anterior chamber intraocular lenses. ${ }^{17}$ Clinical examination and imaging of the macula are possible through the IMT (figures $1 \mathrm{C}$ and $2 \mathrm{~A}-\mathrm{C}$ ), enabling monitoring for progression and treatment of reactivated neovascular AMD. Visualisation of the far peripheral retina is limited; thus, peripheral retinal pathology or high myopia are contraindications for intraocular magnifiers. Though not treating the primary pathology of AMD, intraocular magnifiers, like the IMT, are useful functional adjuncts when medical therapy fails to maintain adequate vision. Though improvement in VA is not always sustained in the long term, the temporary delay in further deterioration positively influences visual QoL and is a useful consideration in this elderly population.

\section{Acknowledgements VisionCare Ophthalmic Technologies (Samsara Vision)}

Contributors KAJS: patient care, manuscript drafting and revision. GM: patient care, manuscript drafting and revision. EA: device design, manuscript drafting and revision. DJK: patient care, manuscript drafting and revision.

Funding The authors have not declared a specific grant for this research from any funding agency in the public, commercial or not-for-profit sectors.

Competing interests KAJS: none. GM: none. DJK: none. EA: device design, employee of VisionCare Ophthalmic Technologies.
Patient consent for publication Obtained.

Provenance and peer review Not commissioned; externally peer reviewed.

\section{ORCID iD}

Kirk A J Stephenson http://orcid.org/0000-0002-7462-7725

\section{REFERENCES}

1 Güell JL, Verdaguer P, Mateu-Figueras G, et al. Unilateral iris-claw intraocular lens implantation for aphakia: a Paired-Eye comparison. Cornea 2016;35:1326-32.

2 Pennington KL, DeAngelis MM. Epidemiology of age-related macular degeneration (AMD): associations with cardiovascular disease phenotypes and lipid factors. Eye Vis 2016;3:34.

3 Zarbin MA. Current concepts in the pathogenesis of age-related macular degeneration. Arch Ophthalmol 2004;122:598-614.

4 Moutray T, Chakravarthy U. Age-related macular degeneration: current treatment and future options. Ther Adv Chronic Dis 2011;2:325-31.

5 Mitchell J, Bradley C. Quality of life in age-related macular degeneration: a review of the literature. Health Qual Life Outcomes 2006;4:97.

6 Shah P, Schwartz SG, Gartner S, et al. Low vision services: a practical guide for the clinician. Ther Adv Ophthalmol 2018;10:251584141877626.

7 Hudson HL, Stulting RD, Heier JS, et al. Implantable telescope for end-stage age-related macular degeneration: long-term visual acuity and safety outcomes. Am J Ophthalmol 2008;146:664-73.

Copyright 2021 BMJ Publishing Group. All rights reserved. For permission to reuse any of this content visit https://www.bmj.com/company/products-services/rights-and-licensing/permissions/

BMJ Case Report Fellows may re-use this article for personal use and teaching without any further permission.

Become a Fellow of BMJ Case Reports today and you can:

- Submit as many cases as you like

- Enjoy fast sympathetic peer review and rapid publication of accepted articles

- Access all the published articles

Re-use any of the published material for personal use and teaching without further permission

Customer Service

If you have any further queries about your subscription, please contact our customer services team on +44 (0) 2071111105 or via email at support@bmj.com.

Visit casereports.bmj.com for more articles like this and to become a Fellow 